Rif'atul Khoiriah Malik

\title{
HERMENEUTIKA AL-QUR'AN DAN DEBAT TAFSIR MODERN: Implementasinya dengan Masa Kini
}

UIN Sunan Kalijaga Yoyakarta

Email: rifah.writer@gmail.com

\begin{abstract}
The interpretation of the Quran which triggered controversial themes in the post-modern era is now an interesting study to be studied. As in this paper, hermeneutics as a new method of interpretation that emerged in Ancient Greece has become part of the interpretation method of the Quran. From this arises a debate over the emergence of the hermeneutical method if applied to the Quran. Will the hermeneutic approach be used in the interpretation of the Quran? How does hermeneutics answer the modern interpretation debate? From this question, the author examines some views on hermeneutics among interpreters, accompanied by the interpretation of several controversial themes that occur in modern societies. Through this paper, it will be seen that, the knowledge that continues to be a reformer in the modern era is something that should not be excluded or rejected. With the aim of scientific upgrading, it is increasingly evolving in time and places, but from that it does not forget the old traditions of returning to the Quran and Hadith.
\end{abstract}

Keywords: Hermeneutics, Alquran, Modern Interpretation.

Abstrak: Penafsiran Alquran yang memicu tema-tema kontroversial di era post-modern saat ini menjadi kajian yang menarik untuk dipelajari. Sebagaimana dalam tulisan ini yaitu hermeneutika sebagai metode penafsiran baru yang muncul di zaman Yunani Kuno telah menjadi bagian dari metode

At-Turäs: Jurnal Studi Keislaman

Volume 6, No.1, Januari-Juni 2019

DOI: http://doi.org/10.33650/at-turas.v6i1.583 
tafsir Alquran. Dari sini timbul perdebatan akan kemunculan metode hermeneutika jika diaplikasikan pada Alquran. Akankah pendekatan hermeneutika bisa digunakan dalam penafsiran al-Qur'an? Bagaimana hermeneutika menjawab debat tafsir modern? Dari pertanyaan ini, penulis mengkaji beberapa pandangan tentang hermeneutika di kalangan mufassir, disertai dengan penafsiran beberapa tema kontroversial yang terjadi di masyarakat modern. Melalui tulisan ini akan dilibat bahwa, keilmuan yang terus menjadi pembaharu di modern era adalah hal yang tidak boleh dikesampingkan atau ditolak. Dengan tujuan upgrade keilmuan semakin berkembang sesuai zaman dan makan, namun dari pada itu tidak melupakan tradisi-tradisi lama yaitu kembali kepada Alquran dan Hadits.

Kata Kunci: Hermeneutika, Alquran, Tafsir Modern.

\section{PENDAHULUAN}

Perkembangan zaman yang saat ini semakin pesat, sebagaimana telah memasuki modern era menciptakan beragam pandangan yang berbeda-beda tentang penafsiran Alquran. Sehingga muncullah tema-tema kontroversial yang pernah muncul dalam sejarah penafsiran Alquran bahkan tentang Alquran sendiri.

Di sini penulis akan menjabarkan secara mendetail beberapa penafsiran Alquran dengan tema-tema kontroversial. Dalam kajian ini penulis menggunakan pendekatan heremeneutika dalam konteks studi Alquran dalam menghadapi perdebatan tafsir modern (Faiz, 2015). Hermeneutika telah banyak menarik perhatian kalangan kesarjanaan Muslim, khususnya mereka para pemerhati studi Alquran. Asumsi paling mendasar dari hermeneutika ini adalah adanya pluralitas dalam proses pemahaman manusia. Pluralitas yang dimaksud sifatnya niscaya, karena pluralitas tersebut bersumber dari keragaman konteks hidup manusia.

Dari keragaman mufassir yang berbeda inilah menimbulkan pemaknaan yang beragam sesuai dengan teks, konteks, dan kontekstual. Sehingga penafsiran Alquran oleh para Ulama tafsir klasik memberikan solusi dari pelbagai persoalan yang mereka hadapi, baik persoalan ketuhanan, maupun persoalan kemanusiaan. Karena pelbagai persoalan yang dihadapi masing-masing mufassir berbeda-beda, pesan Qurani yang lahir pun berbeda-beda dan plural. 
Namun, pluralitas makna atau pesan Alquran itu menjadi sirna tatkala kreasi tafsir klasik yang awalnya bersifat profan itu mulai "menteologi" dan dijadikan sebagai satu-satunya penafsiran yang dinilai paling benar. Para mufassir belakangan dituntut merujuk pada tafsir klasik tersebut tanpa melihat kondisi kebutuhan riil umat Islam pada masing-masing ranah ruang dan waktu.

Dari sini bisa dilihat bahwa penafsiran Alquran yang kian kompleks dan sesuai zaman sebagaimana dalam ungkapannya shalih li kulli zaman wa makan adalah hal yang tidak bisa dielakkan. Sehingga penafsiran yang seharusnya berpusat pada Alquran dan Sunnah adalah jalan yang paling bijak. Selain itu, zaman modern saat ini yang mana tidak ada Rasul sebagaimana Nabi Muhammad SAW kepada ummatnya. Memiliki tokoh yaitu orang-orang yang berilmu dan mengikuti jalan Rasul, seperti tabi'in, tabi'u at-tabi'in dan seterusnya, kini kita kenal dengan sebutan Ulama/Wali adalah salah satu panutan yang patut digunakan sebagaimana fatwa-fatwanya dalam ijma' dan ijtihadnya.

Namun dari pada itu, khazanah intelektual Islam tentang Alquran yang tak pernah berhenti dengan munculnya metode tafsir kontemporer yang dipicu oleh kekhawatiran yang akan ditimbulkan ketika penafsiran Alquran dilakukan secara tekstual, dengan mengabaikan situasi dan latar belakang turunnya suatu ayat sebagai data sejarah penting (Syamsuddin, 2003).

Berangkat dari uraian di atas, maka penulis dalam artikel ini akan berusaha menspesifikasi kajiannya pada tafsir kontemporer dengan memaparkan beberapa contoh beserta bahasannya dengan menggunakan pendekatan hermeneutika. Sebagaimana peralihan zaman klasik ke zaman modern menyebabkan munculnya beberapa penafsiran yang berkembang sesuai zaman dan makan.

\section{PEMBAHASAN}

\section{Hermeneutika dalam Penafsiran Al-Qur'an}

Kehadiran hermeneutika tidak terlepas dari persoalan mendasar yaitu terkait dengan otentisitas teks Bibel dan makna asal yang terkandung di dalamnya (Muzayyin, 2015). Meskipun hermeneutika bisa dipakai sebagai alat untuk "menafsirkan" berbagai bidang kajian keilmuan, melihat sejarah kelahiran dan 
perkembangannya, harus diakui bahwa peran Hermeneutika yang paling besar adalah dalam bidang ilmu sejarah dan kritik teks, khususnya kitab suci (Faiz, 2015).

Kegiatan penafsiran menurut Harley, selalu berkaitan dengan tiga unsur dalam interpretasi: pertama, tanda, pesan, atau teks dari berbagai sumber (Author). Kedua, seorang mediator yang berfungsi menerjemahkan tanda (Reader) sehingga dapat dengan mudah dipahami, dan ketiga audience yang menjadi tujuan sekaligus penerima hasil dari penafsiran yang ditafsirkan. Ketiga unsur di atas saling berhubungan secara dialektis dan masing-masing memberi sumbangan bagi proses pembentukan makna (Anshari, 2009). Dari situ muncullah sebuah teori interpretasi yang dikenal dengan hermeneutika.

Tugas pokok hermeneutika adalah menafsirkan sebuah teks klasik atau teks yang asing sama sekali dan menjadi milik orang yang hidup di zaman, tempat, serta suasana kultural yang berbeda. Berkaitan dengan tugas hermeneutika tersebut, ada sebuah ungkapan yang ditulis oleh Roger Trigg dalam sebuah buku Understading Social Science yang dikutip Komaruddin Hidayat, thought without language becomes impossible, and different languages will produces different thought. Bahwasanya, berpikir itu tidak mungkin dipisahkan dari bahasa, dan adanya perbedaan bahasa akan melahirkan perbedaan produk pemikiran (Muflihah, 2012). Apabila bahasa dan pikiran menentukan pemakknaan terhadap dunia sekelilingnya, maka memahami teks mensyaratkan untuk memahami tradisi di mana teks dilahirkan. Artinya, pemahaman sebuah teks hendaknya tidak boleh lepas dari konteksnya.

Hermeneutika yang menjadi sebuah penawaran metodologi baru bagi pengkajian kitab suci, menjadikan keberadaannya tidak bisa dielakkan dari dunia kitab suci Alquran. Menjamurnya literature kajian ilmu Tafsir kontemporer menawarkan hermeneutika sebagai variabel metode pemahaman Alquran menunjukkan betapa daya tarik hermeneutika memang luar biasa. Hassan Hanafi dalam tulisannya Religious Dialogue and Revolution menyatakan bahwa Hermeneutik itu tidak sekedar ilmu interpretasi atau teori pemahaman, tetapi juga berarti ilmu yang menjelaskan penerimaan wahyu sejak dari tingkat perkataan sampai tingkat dunia. Ilmu tentang proses wahyu dari huruf sampai kenyataan, dari logos sampai 
praktis dan juga transformasi wahyu dari pikiran Tuhan kepada kehidupan manusia.

Dalam kajian keilmuan Islam sebelum datangnya hermeneutika telah dikenal "tafsir" (Syamsuddin, 2003). Kata yang asalnya dalam bahasa Arab fassara atau fasara ini digunakan secara teknis dalam pengartian eksegesis di kalangan orang Islam dari abad ke-5 hingga sekarang. Menurut Farid Esack dalam bukunya Quran: Pluralism and Liberation, praktek Hermeneutik sebenarnya telah dilakukan oleh umat Islam sejak lama, khususnya ketika menghadapi Alquran. Bukti dari hal itu adalah:

1. Problematika hermeneutik itu senantiasa dialami dan dikaji, meski tidak ditampilkan secara definitif. Hal ini terbukti dari kajian-kajian mengenai asbabun-nuzul dan nasakh-mansukh.

2. Perbedaan antara komentar-komentar yang aktual terhadap Alquran (tafsir) dengan aturan, teori atau metode penafsiran telah ada sejak mulai munculnya literatur-literatur tafsir yang disusun dalam bentuk ilmu tafsir.

3. Tafsir tradisional itu selalu dimasukkan dalam kategori-kategori, misalnya tafsir syi'ah, tafsir mu'tazilah, tafsir hokum, tafsir filsafat, dan lain sebagainya. Hal itu menunjukkan adanya kesadaran tentang kelompok-kelompok tertentu, ideologiideologi tertentu, periode tertentu, maupun horizon social tertentu dari tafsir (Syamsuddin, 2003).

Dari ketiga hal di atas memperjelas bahwa adanya kesadaran akan historisitas pemahaman yang berimplikasi terhadap pluralitas penafsiran. Oleh karena itu, meskipun tidak disebut secara definitif, dapat dikatakan corak hermeneutik yang berasumsi dasar pluralitas pemahaman ini sebenarnya telah memiliki bibit-bibitnya dalam Ulumul Quran klasik.

Kalangan ilmuan klasik dan modern telah sepakat tentang pengertian hermeneutik, yang diartikan sebagai proses mengubah sesuatu dari situasi ketidaktahuan menjadi mengerti. Pengertian tersebut merupakan peralihan antara sesuatu yang abstrak dan gelap kepada ungkapan yang jelas dalam bentuk bahasa yang dapat dipahami oleh manusia. Hermeneutik juga diartikan dengan menerjemahkan dan bertindak sebagai penafsir.

Apabila dilihat lebih mendalam keberadaan hermeneutik dapat dilacak sampai zaman Yunani Kuno. Pada waktu itu, sudah 
ada diskursus hermeneutik sebagaimana yang terdapat dalam tulisan Aristoteles yang berjudul Peri Hermenians (de interpretation) (Syamsuddin, 2003). Hermeneutika dalam perjalanannya sebagai wacana dikemukakan oleh Richard E. Palmer. Palmer (Syamsuddin, 2003) memberikan peta hermeneutik sebagai berikut:

Pertama, hermeneutik sebagai teori penafsiran Kitab Suci. Hermeneutik dalam bentuk ini terdapat dalam tradisi gereja di mana masyarakat Eropa mendiskusikan otensitas Bibel untuk mendapatkan kejelasan akan maknanya. Hermeneutik identik dengan interpretasi. Kenyataan ini acapkali termanifestasikan sampai sekarang, terutama jika dihubungkan dengan penafsiran kitab suci (exegesis of scripture) bentuk hermeneutik semacam ini dikaji oleh J. C. Dannhauer's. Kajian semacam ini memiliki area macam bentuk dan melahirkan berbagai corak pemikiran, seperti yang dilakukan Martin Luther yang memberikan interpretasi dalam Bibel melalui mistik, dogmatik, humanis, dan lain sebagainya.

Kedua, hermeneutik sebagai sebuah metode filologi. Dimulai dengan munculnya rasionalisme dan hal-hal yang berhubungan dengannya. Perjalanan filologi klasik pada abad 18 mempunyai pengaruh pada hermeneutik Bibel. Pernyataan ini menimbulkan kritik sejarah dalam teologi. Kajian dalam bentuk semacam ini dimulai oleh Ernesti pada 1761 M. Sampai akhirnya corak ini dianggap sebagai metode penafsiran sekuler oleh pihak gereja. Namun, sejak munculnya abad pencerahan di Eropa sampai sekarang, metode Bibel tidak dapat dipisahkan dengan metode research dalam filologi. Kehadiran dalam bentuk ini mulai tampak pada abad 19 M yang sering didiskusikan oleh filolog, Scheiemarcher, Frederich August Wolf dan Friedrich Ast. Ia memberikan porsi yang sama dengan tafsir terhadap kitab suci dan teks lainnya.

Ketiga, hermeneutik sebagai ilmu pemahaman linguistic (science of linguistic understanding). Scheiemarcher membedakan hermeneutik sebagai science (ilmu) dan hermeneutik sebagai art (seni) dalam memahami. Bentuk memahami dalam hermeneutik merupakan arti secara umum dalam keilmuan hermeneutik dan hal ini masih digunakan sampai saat ini. arti tersebut merupakan asal dari hermeneutik. Oleh karena itu, dalam perspektif historis, hermeneutik dianggap sebagai pahlawan dalam penafsiran Bibel 
serta filologi tradisional. Sebab dengan munculnya kedua bentuk disiplin tersebut, menandai adanya pemahaman secara linguistic (bahasa) terhadap teks.

Keempat, hermeneutik sebagai pondasi ilmu kemanusiaan. Kerangka hermeneutik dalam bentu ini dimulai Wilhelm Dilthey. Ia berusaha membawa hermeneutik dalam menafsirkan ilmu kemanusiaan, seperti menginterpretasikan ekspresi kehidupan manusia. Dilthey memberikan kritik terhadap Kant terutama dalam pure reasonnya. Diakhir perkembangan pemikiran Dilthey, ia berusaha menginterpretasikan psikologi dalam memahami dan menginterpretasikan.

Kelima, hermeneutik sebagai fenomena das sein dan pemahaman eksistensial. Corak hermeneutik ini diungkap pertama kali oleh Martin Heidegger yang berangkat dari filsafat eksistensialisnya yang dipengaruhi gurunya, Etmund Hesserl. Dalam perjalanannya, bentuk hermeneutik filosofis ini dikembangkan oleh Gadamer yang memberikan perhatian lebih terhadap hermeneutik dalam kaitannya dengan filsafat. Ia tidak percaya dengan adanya metode tertentu dalam mendapatkan hasil yang baik dalam menginterpretasikan teks.

Keenam, hermeneutik sebagai sistem penafsiran. Bentuk pemaknaan hermeneutik merupakan suatu teori tentang seperangkat aturan yang menentukan suatu interpretasi eksegesis suatu bagian dari teks atau sekumpulan tanda yang dianggap sebuah teks. Kajian tipe terakhir dari hermeneutik ini dikemukakan oleh Paul Ricoeur.

Adapun pemaknaan hermeneutika tentang bagaimana memahami Alquran menurut tradisi Islam pendapat Ibnu 'Arabi berkeyakinan bahwa teks Alquran mengandung makna yang sangat dalam dan tak terhingga. Setiap kata di Alquran memiliki makna yang tak terbatas, yang semuannya dikendaki oleh Tuhan. Oleh karena itu, Alquran bisa ditafsirkan secara beragama sesuai dengan pengalaman keberagamaan setiap mufassir. Di sini muncullah konsep pluralitas agama yang diusung Ibnu 'Arabi (Pari, 2009). Selain itu dalam pendekatan fenomenologi Hanafi, hermeneutika adalah ilmu yang menentukan relasi antar kesadaran dengan objeknya, yakni kitab suci (Pari, 2009). 
Dari beberapa pedapat tokoh mengenai hermeneutik di atas, dapat disimpulkan bahwa hermeneutik cenderung digunakan dalam penafsiran Bibel. Sehingga apabila hermeneutik digunakan sebagai metode penafsiran Alquran mendapatkan pro-kontra antara mufassir. Hal ini penting diurai lebih lanjut mengenai argumentasi yang dibangun oleh masing-masing mufassir (Muzayyin, 2015). Tokoh hermeneutik seperti Schleiermacher, Dilthey, Gadamer, dan lainlain memandang agama sebagai bentuk interpretasi dari interpretasi (Muzir, 2016). Dalam kondisi yang demikian, sangat logis bila secara konseptual heremeneutik mengisyaratkan bahwa tidak suatu teks yang tak dapat ditafsirkan oleh hermeneut. Di sinilah bedanya dengan ilmu tafsir, di mana diajarkan tidak semua teks (ayat) Alquran dapat dipahami maknanya secara jelas. Dalam konteks ini, "Abd Allah Ibn "Abbas yang menyandang predikat sebagai "juru bicara Alquran" menegaskan bahwa tafsir Alquran terbagi ke dalam empat kategori. Pertama, dapat diketahui secara umum melalui bahasa Arab. Kedua, tidak ada alasan untuk tidak mengetahuinya seperti ayat-ayat tentang halal dan haram. Ketiga, hanya dapat dipahami oleh para ulama. Keempat, hanya Allah saja yang tahu maknanya (Syamsuddin, 2003).

Pada akhirnya apa yang ditawarkan oleh hermeneutik dalam menafsirkan teks, linguistic, sejarah, agama, dan disiplin ilmu yang lainnya adalah suatu kreasi, karya, dan bikinan manusia. Karena itu, ia mempunyai kelemahan yang tidak bisa ditutupi. Terlebih lagi jika dia berdiri sendiri tanpa dialog dengan lainnya.

\section{Studi Debat Tafsir Modern}

Perputaran waktu dari zaman klasik hingga saat ini memasuki zaman modern terjadi problema dan pola hidup yang sangat berbeda dengan zaman dahulu. Sebagaimana di zaman Rasul yang menggunakan Unta sebagai kendaraan dari Makkah ke Madinah, kini muncul unta-unta berjalan dengan sekali gas. Seperti, Honda dkk. Hal ini tidak bisa dipungkiri bahwa zaman akan semakin berkembang, namun Alquran sebagai pedoman Umat Muslim tidak pernah berubah meski telah melewati 21 abad. Sebagaimana ungkapan yang berbunyi "Alquran sholibun li kulli zaman wa makan" yaitu Alquran sesuai dengan waktu dan tempat. Namun, sesuai dengan perkembangan zaman penafsiran Alquran juga 
menyesuaikan latar belakang masyarakat yang berkembang pada masa saat ini.

Tapi meskipun begitu, tidak sepenuhnya keseluruhan terdapat perbedaan secara signifikan dari pola dan pendekatan yang terdapat pada tafsir-tafsir terdahulu, ada kalanya penafsiran modern masih harus bertumpu pada tafsir klasik. Adapun rujukannya biasanya mengambil dari sumber-sumber klasik seperti karya Fakhrudin Al-Razi, Zamakhsyari dan Ibnu Katsir (Rahman, 2017).

Salah satu pemikir Muslim besar yang banyak memberi warna dan inspirasi pada kebangkitan dunia intelektual Islam adalah Muhammad Abduh (1649-1905). Meskipun pemikir ini dianggap sebagai neo-Mu'tazilah, tetapi isu yang dibawa tentu lain dengan Mu'tazilah ala al-Zamakhsyari. Salah satu titik tekannya dalam dunia tafsir adalah sikap anti-irrasional, termasuk upaya demitologisasi. Walhasil, sesuatu yang tampak kurang rasional dicoba dijelaskan dengan perspektif rasional modern.

Adanya metode tafsir hermeneutika, hendaknya bisa menjadi bagian dari salah satu pendekatan penafsiran di masa modern saat ini, meski pendekatan ini menuai banyak pro kontra, meskipun begitu kelompok yang menerima dan menolak hermeneutika sebenarnya mempunya tujuan yang sama, yakni menjelaskan maksud dan pesan Alquran sebagai kitab petunjuk pada umat manusia yang sesuai pada setiap waktu dan tempat (Shalih likulli zaman wa makan).

Kalangan yang menerima berupaya untuk membumikan ajaran Alquran sesuai dengan konteksnya. Sedangkan yang menolak merasa berkewajiban untuk menerapkan Alquran dalam kehidupan kaum muslimin sepanjang masa, sebagaimana yang telah dipahami oleh ulama secara literal dan mempertahankan metode yang genuine dan sangat mapan yang telah dirumuskan salafus shalih yakni metode tafsir dan takwil yang tidak bisa disepadankan dengan hermeneutika (Victoria, 2017).

Melalui problema di atas, terjadilah debat tafsir modern yang akan dijabarkan penulis di bawah ini:

1. Metodologi Tafsir Perspektif Gender

Persoalan gender menjadi sebuah hal yang selalu diperbincangkan. Terutama di era modernisasi saat ini, gender tak lepas dari bagaimana peran sosial antara wanita dan pria 
menduduki peran yang sama. Sebagai agama universal, Islam menjembatani persamaan fungsi dan peran sosial tersebut. Kesetaraan fungsi dan peran laki-laki dan perempuan merupakan bagian dari nilai-nilai ilabiyah dan nilai-nilai esensial tersebut merupakan hikmah yang dalam terhadap adanya kesetaraan gender.

Terjadinya gerakan feminis yang mengangkat isu-isu gender dalam memahami Alquran telah memberikan kontribusi corak metodologi yang berbeda dari sebelumnya (Mustaqim, 2001). Hal ini menyebabkan kaum feminis merasa "gerah" melihat perlakuan terhadap perempuan di masyarakat. Acap kali perempuan diposisikan secara subordinat dan kurang dihargai. Dengan posisi yang kurang menguntungkan tersebut, konsekuensinya perempuan harus tunduk kepada laki-laki seakan mendapatkan legitimasi dari doktrin-doktrin teologis atau agama; berupa penafsiran yang sarat dengan bias gender. Bahkan hal ini juga didukung dengan adanya system patriarkhi yang sedemikian kuat melekat di masyarakat kita (Salim, 1997).

Dengan kuatnya sistem budaya androsentris-patriarkhi yang didukung oleh teologis membuat perempuan bearada dalam posisi marginal dan subordinat di bawah kaum laki-laki. Oleh sebab itu, wajar jika kemudian muncul pertanyaanpertanyaan seperti apakah perempuan secara kodratnya memang benar-benar di bawah kaum laki-laki? Ataukah hal itu sebenarnya banya merupakan social construction lewat proses sosio-bistoris yang panjang akibat kuatnya system patriarkhi, sehingga perempuan tidak mampu bersaing secara sehat dengan kaum laki-laki? Bagaimana sebenarnya pandangan Islam terhadap perempuan? Dengan adanya beberapa pertanyaan di atas, penulis akan menjelaskan secara kritis terhadap wacana tafsir yang dipandang bias patriarkhi melalui kaca mata metodologi tafsir yang ditawarkan Riffat Hassan (Mustaqim, 2001).

Terjadinya bias gender tidak lain karena pemahaman yang kurang meneyluruh akan sebuah ayat. Menurut penelitian Nasaruddin Umar, salah satu bukti bentuk metode tafsir yang bias gender adalah metode tafsir tablili atau tajzi $i$. Metode ini cenderung bersifat parsial (sepotong-sepotong) dalam menangkap pemaknaan Alquran, sehingga tidak utuh. Hal ini 
tampak sekali ketika para mufassir dulu menafsirkan ayat-ayat poligami. Metode tablili terkesan mempermudah untuk mengizinkan seseorang untuk berpoligami asal dapat memenuuhi syarat adil. Tetapi dengan metode maudhu'i (holistik) misalnya, kesimpulan akan berbeda sebab di ayat lain terdapat penjelasan akan kemustahilan syarat adil untuk dapat dilakukan oleh manusia. Hal ini dapat dilihat dari ayat Q.S anNisa' 129;

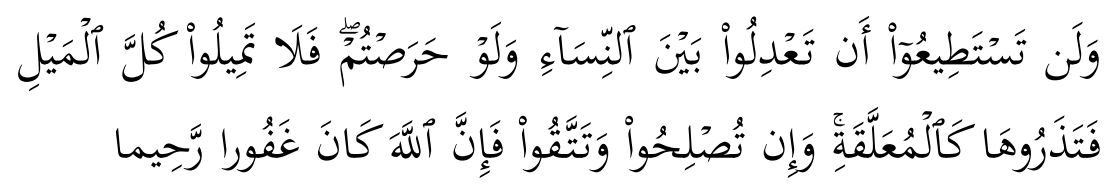

"Dan kamu sekali-kali tidak akan dapat berlaku adil di antara isteri-isteri (mu), walaupun kamu sangat ingin berbuat demikian, karena itu janganlah kamu terlalu cenderung (kepada yang kamu cintai), sehingga kamu biarkan yang lain terkatung-katung. Dan jika kamu mengadakan perbaikan dan memelibara diri (dari kecurangan), maka sesunggubnya Allah Maha Pengampun lagi Maha Penyayang".

Menurut Riffat, yang mutlak dan penting untuk diingat dalam menafsirkan Alquran adalah bahwa ayat-ayat yang ada di dalamnya sangat beragam sifatnya. Ada ayat yang artinya jelas dan gamblang (mubkamat) sehingga bisa langsung dijadikan pedoman aturan hukum. Namun di sisi lain, ada pula ayat-ayat yang bersifat simbolik atau pralambang, bahkan Alquran juga memuat cerita-cerita dan mitologi-mitologi yang penuturannya juga dibungkus dalam pralambang.

Untuk menafsirkan ayat-ayat Alquran yang dapat dipandang "steril" dari bias gender, Riffat Hassan mencoba menawarkan konstruksi metode penafsiran baru yaitu metode hostoris-kritis-kontekstual. Adapun cara kerja metode ini adalah Pertama, dengan memeriksa ketepatan makna kata atau bahasa (language accuracy), yaitu dengan melihat terlebih dahulu secara kritis sejarah kata dan akar katanya sesuai dengan konteks pada waktu itu. Selanjutnya, Riffat melihat dengan analisis 
semantiknya (yang berkaitan dengan arti kata), bagaimana konteks saat itu dan bagaimana kondisi sosio kulturalnya. Kedua, melakukan pengujian atas konsistensi filosofis dari penafsiranpenafsiran yang telah ada. Ketiga, prinsip etis dengan didasarkan pada prinsip keadilan yang merupakan pencerminan dari Justice of God (Mustaqim, 2001).

Berikut adalah aplikasi dan implikasi teoretis metode yang ditawarkan Riffat Hassan;

a. Teori Penciptaan (Theory of Creation)

Dalam diskursus feminisme, konsep penciptaan perempuan merupakan isu yang sangan penting dan mendasar untuk diteliti terlebih dahulu, baik ditinjau secara filosofis maupun teologis disbanding dengan isu-isu feminism yang lain. Sebab konsep kesetaraan atau ketidaksetaraan dapat dilacak akarnya dari konsep penciptaan perempuan.

Menurut Riffat, Adam dan Hawa diciptakan secara serempak dan sama subtansinya, sama pula caranya. Bukan adam diciptakan lebih dulu dari tanah, kemudian Hawa dari tulang rusuk Adam sebagaimana kebanyakan pendapat para mufassir dan bahkan hampir seluruh umat Islam. Sebagaimana pendapat Riffat, istri Adam (Hawa) dijadikan dari jenis yang sama. Kata nafs wabidab ditafsirkannya dengan jenis yang satu (jinsun wabidun).

b. Kedudukan perempuan

Beberapa penyebab adanya asumsi-sumsi teologis yang menyatakan bahwa perempuan dianggap tidak setara dengan laki-laki menurut Riffat sebagai berikut (Mustaqim, 2001): (1) bahwa ciptaan Tuhan yang pertama adalah lakilaki (Adam) bukan perempuan. (2) perempuan dilukiskan sebagai penyebab utama kejatuhan atau pengusiran manusia dari surga. Oleh karena itu, perempuan dipandang dengan rasa benci, curiga, dan jijik. (3) perempuan diciptakan bukan hanya dari laki-laki tapi juga untuk laki-laki, yang membuat eksistensinya semata-mata bersifat instrumental dan tidak memiliki makna yang mendasar.

Alquran telah menjelaskan bahwa kedudukan perempuan dan laki-laki setara (al-Musawah) yang 
menginginkan hidup dalam harmoni dan kesalihan bersama. Sebagaimana Riffat mengutip ayat-ayat Alquran antara lain: al-Imran: 195, an-Nisa': 124 dan al-Ahzab: 35 sebagai berikut.

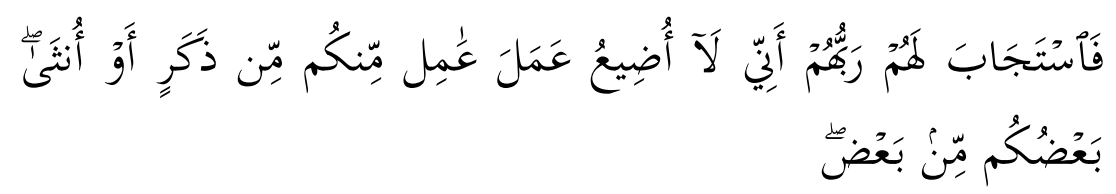

"Maka Tuhan mereka memperkenankan permohonannya (dengan berfirman): "Sesunggubnya Aku tidak menyia-nyiakan amal orang-orang yang beramal di antara kamu, baik laki-laki atau perempuan, (karena) sebagian kamu adalah turunan dari sebagian yang lain” (Q.S al-Imran: 195).

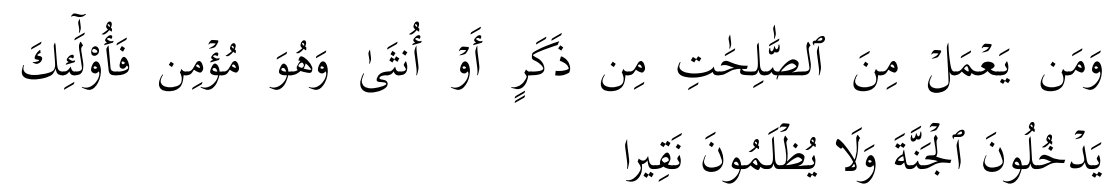

"Barangsiapa yang mengerjakan amal-amal saleh, baik laki-laki maupun wanita sedang ia orang yang beriman, maka mereka itu masuk ke dalam surga dan mereka tidak dianiaya walau sedikitpun” (Q.S an-Nisa': 124).

Sebagaimana yang dengan ayat-ayat di atas, jelas bahwa kedudukan laki-laki dan perempuan tidak terdapat ketimpangan. Tuhan begitu Maha Adil memposisikan perempuan dalam Alquran bahkan tampak memuliakan perempuan dengan memberi perhatian kepada mereka yang terpinggirkan, para janda, anak-anak yatim, kaum budak dari pada mereka yang kaya dan berkuasa. Dengan demikian Alquran tidak membuat diskriminasi atau perbedaan perempuan dan laki-laki.

c. Konsep poligami

Realitas sejarah bahwa Rasulullah melakukan poligami menjadi sandaran bahwa poligami diperbolehkan. Perdebatan poligami yang merupakan isu klasik menjadi 
menarik untuk dikaji. Adapun pendapat pro poligami yang berlandaskan sunnah Nabi menjadi landasan dasar bagi mereka yang berpoligami. Sebagaimana di dalam Alquran hanya terdapat satu ayat yang berbicara tentang poligami, an-Nisa' ayat 3:

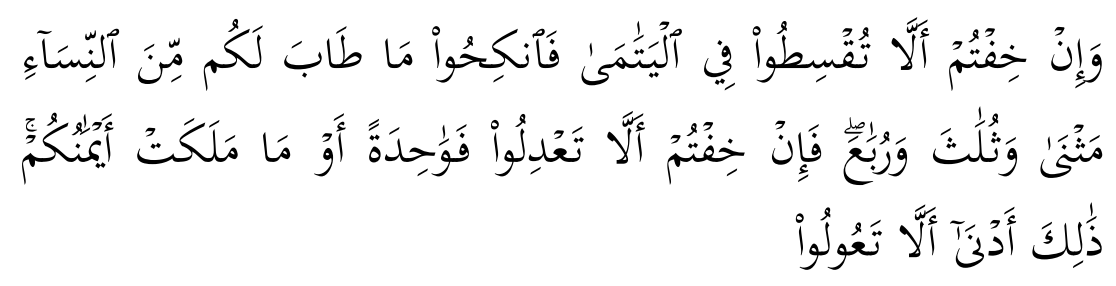

"Dan jika kamu takut tidak akan dapat berlaku adil terhadap (bak-bak.) perempuan yang yatim (bilamana kamu mengawininya), maka kawinilah wanita-wanita (lain) yang kamu senangi: dua, tiga atau empat. Kemudian jika kamu takut tidak akan dapat berlaku adil, maka (kawinilah) seorang saja, atau budak-budak yang kamu miliki. Yang demikian itu adalab lebih dekat kepada tidak berbuat aniaya.

Menurut Riffat, ayat ini banyak ditafsirkan secara keliru oleh kebanyakan mufassir. Dalam Alquran maupun dalam keseharian Nabi Muhammad SAW, memelihara anak yatim atau anak yang terlantar selalu mendapat perhatian besar dan dianggap sangat penting. Izin poligami sesungguhnya berkaitan erat dengan masalah tersebut. Jika, kita mau membaca kembali ayat plogami si atas, sebenarnya masalah utamanya adalah penyantunan anak yatim. Jadi, yang dimaksud "pernikahaan dalam ayat itu adalah menikahi ibu anak yatim. Penafsiran ini tidak bisa diragukan lagi karena ayat itu turun ketika banyak terjadi perang dan banyak dari laki-laki yang meninggal sehingga menyebabkan banyak janda dan anak-anak yatim. Oleh sebab itu, sebenarnya pesan moral Alquran tentang masalah ini adalah: (1) agar anak yatim ini dipelihara dan disantuni, (2) ayat ini bicara tentang keadilan, sehingga dapat disimpulkan bahwa poligami sebenarnya hanya dibolehkan dalam kondisi sulit seperti itu. Hal ini juga pernah dinyatakan oleh Muhammad 
Shahrur, seorang pemikir Islam Kontemporer dari Syiria yang cukup kontroversial "Sesungguhnya poligami itu terkait dengan konteles yang sangat darurat dan pada dasarnya Islam menganut prinsip monogami".

Jika kita kembali melihat sejarah, Rasulullah SAW pertama menikahi Sayyidah Khadijah pada umur 25 tahun dan itu merupakan perkawinan terpenting bagi beliau. Nabi tidak menikah lagi sampai umur 50 tahun, jadi selama masa suburnya beliau menikah hanya sekali dan tidak berpoligami. Dengan demikian jelas bahwa pernikahan Nabi setelah wafatnya Khadijah bukan untuk memperturutkan nafsu seksnya, akan tetapi lebih kepada penyantunan jandajanda dan anak yatim. Di samping itu, dalam poligami Nabi ada hikmah yang bersifat edukatif, psikologis, ekonomis, dan bahkan politis. Sebab dipikir secara logika, jika Nabi menginginkan tuntutan seksnya, mestinya beliau menikahi gadis-gadis yang masih muda dan perawan. Akan tetapi mengapa hal itu tidak dilakukan oleh beliau?

2. Debat Hukum Meminum Air Kencing Unta

Ketua Gerakan Nasional Pengawal Fatwa Majelis Ulama Indonesia (GNPF-MUI), Bachtiar Nasir yang sempat viral di tahun lalu akibat videonya yang diunggah sedang meminum air seni unta. Menimbulkan kontroversi dan beragam pandangan di kalangan masyarakat khususnya Indonesia.

Dalam unggahannya, Bachtiar mengutip beberapa hadits yang menyebut fungsi air seni dan susu unta yang memiliki khasiat kesehatan tersendiri. "Rasanya, agak-agak, pahit-pahit sedikit," kata Bachtiar dalam video tersebut. Bachtiar menyebut lagi bahwa menurut penelitian - yang tak disebutkan sumbernya - kencing unta "bisa menyembuhkan penyakit sel-sel kanker di dalam tubuh manusia" (t.n., 2018).

Dalil mengenai khasiat kencing unta disebutkan dalam hadis riwayat Bukhari dan Muslim dengan banyak redaksi. Diantaranya adalah riwayat dari Anas bin Malik radhiyallahu 'anbu, beliau bercerita (Baits, 2018), 


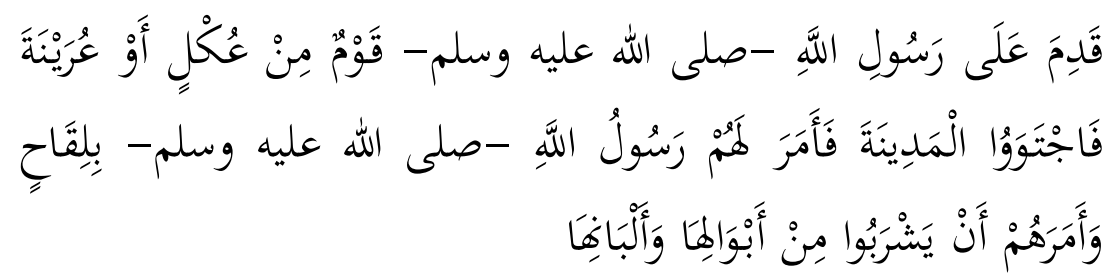

"Ada sejumlah orang dari suku Ukl dan Uranah yang datang menemui Nabi shallallabu 'alaibi wa sallam. Namun mereka mengalami sakit karena tidak betah di Madinah. Lalu Rasulullah shallallabu 'alaibi wa sallam memerintabkan mereka untuk mendatangi kandang unta, dan menyuruh mereka untuk minum air kencingnya dan susunya (HR. Bukhari 1501 \& Muslim 4447).

Dan mengenai khasiat air kencing unta juga diakui oleh Ibnu Sina - ahli kedokteran masa silam -,

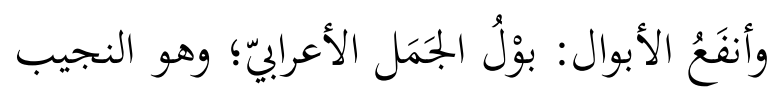

"Kencing yang paling bermanfaat adalah air kencing unta pedalaman arab, dan itu unta pilihan (Dinukil Ibnul Qoyim dalam Zadul Ma'ad).

Adapun perihal sikap kita terhadap hadits yang memperbolehkan meminum air kencing unta, kita sebaiknya hati-hati. Kita boleh mengikuti pandangan yang mana saja tanpa harus menyalahkan pandangan orang lain yang berbeda dengan kita.

Sedangkan dalam hemat kami, kita perlu melihat hadits tersebut dalam kaitannya misalnya dengan pengobatan. Dalam konteks ini, kita bisa melihat kembali bagaimana para ulama ushul fikih memetakan perbuatan Rasul ke dalam dua bagian besar yaitu; Pertama, perbuatan yang disyariatkan, yaitu shalat, puasa, zakat, haji, jual beli, dan seterusnya yang perlu diikuti soal sah dan tidaknya. Kedua, perbuatan Rasul yang tidak disyariatkan sehingga tidak wajib diikuti. 
Ulama ushul fikih merinci perbuatan rasul jenis kedua yang bukan termasuk bagian dari syariat menjadi tiga kategori. Pertama, perbuatan Rasul sebagai makhluk hidup yaitu makan, minum, tidur, lari, duduk, jalan. Kedua, perbuatan Rasul sebagai makhluk budaya (pengalaman dan eksperimen dalam soal keduniaan, bisa ditiru dan bisa dikoreksi) yaitu perdagangan, pertanian, strategi perang, pengaturan tentara, soal pengobatan, dan bidang lainnya. Rasulullah pernah dikoreksi oleh petani kurma Madinah yang gagal panen karena mempraktikkan teknik pertanian yang dianjurkan oleh Rasulullah SAW. Rasulullah juga pernah dikoreksi oleh salah seorang sahabat yang lebih berpengalaman dalam hal perang perihal penempatan pasukan di lokasi tertentu. Ketiga, perbuatan rasul yang bersifat khusus yaitu beristri lebih dari empat orang, memutuskan perkara dengan seorang saksi, puasa wishal, kewajiban shalat dhuha, tahajud, witir.

Terlepas dari perbedaan pendapat empat madzhab, hadits yang memperbolehkan minum air kencing unta untuk kepentingan pengobatan dapat dipahami berdasarkan kategori kedua. Artinya, meminum air kencing unta dapat dibenarkan untuk kepentingan pengobatan dengan catatan, pertama tidak ada lagi obat lain selain air kecing unta, kedua air kencing unta terbukti secara klinis mutakhir merupakan obat atas penyakit tersebut. Artinya, pertimbangan ilmu pengetahuan medis paling mutakhir perlu menjadi pertimbangan utama dalam hal ini. Jangan sampai justru mendatangkan bakteri, membuat mudharat baru secara medis, atau tidak memberikan efek positif apapun sementara kotoran binatang itu terlanjur masuk ke tubuh kita.

Dengan keberadaan kita saat ini, di era modern tentu pengobatan-pengobatan yang canggih sudah bermunculan. Hal ini berimplikasi apabila masih tersedia obat yang lain selain sesuatu yang najis, lebih baik untuk dihindari. Sebagaimana ungkapan Quraish Shihab bahwa pengobatan yang dilakukan Nabi pada saat itu adalah pengobatan yang sesuai zamannya pada saat itu, sehingga tidak menutup kemungkinan pengobatan masa kini berbeda dengan masa Nabi. 
Dari beberapa perdebatan penafsiran di atas, dapat dilihat bahwa setiap mufassir berperan penting sebagaimana tingkat keilmuan, pendidikan, sosio-kultural di mana ia berada. Sebagaimana Riffat Hassan yang dibesarkan di dalam kukungan patriarkal, ia terinspirasi dari ibunya yang memilik paham feminis radikal hingga bisa mempertahankan beberapa argument yang ia miliki secara kritis. Meski dari itu tentu setiap mufassir adalah insan biasa yang juga memiliki titik kelemahan, bukan seperti Nabi yang sudah ma'sum. Sehingga dari sini, sebagai akademisi tentu harus lebih bijak dalam menerima segala perbedaan penafsiran yang telah dijitihadkan. Tentu dengan menghargai setiap pendapat adalah jalan yang paling baik.

Di atas hanya sebagian kecil dari beberapa penafsir modern-kontemporer yang penulis ambil. Seiring berkembangnya zaman tentu kita akan menemukan beragam polemik yang muncul dan hal itu belum sama sekali terjadi. Terlepas dari itu, sebagai umat Muslim kembali merujuk pada Alquran dan Hadits. Alquran menjadi bukti akan setiap kejadian yang terjadi di masa lampau pasti akan kembali terjadi, selain itu Alquran berbicara bahwa perkembangan sejarah dan perkembangan social setiap umat itu berjalan di atas sunnah (hukum) perkembangan yang tetap (Goldziher, 2010). Sebagaimana termaktub dalam Q.S al-Ahzab, 62;

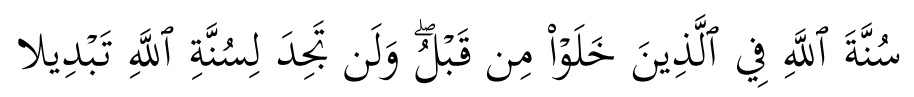

"Sebagai sunnah Allab yang berlaku atas orang-orang yang telah terdahulu sebelum(mu), dan kamu sekali-kali tiada akan mendapati peubahan pada sunnah Allah.

Dari sini, nash selalu diambil sebagai dalil (bukti) atas ketetapan hakikat dari realitas factual ini. maka sunnah Allah Swt yang tidak mengalami perubahan dan tidak mengalami pergantian adalah sunnah (hukum-hukum) yang berlaku dalam sejarah. 


\section{PENUTUP}

Masa modern adalah masa yang di mana segala hal mampu dilakukan dengan mudah, yang dikenal dengan dunia serba instan. Hal ini menyebabkan mudahnya meretas beragam keilmuan hanya dengan menggunakan tekhnologi masa kini. Dengan meningkatnya era informasi saat ini, akan memudahkan para Ulama, akademisi, politis dalam menggunakan media sebagai pembaharu keilmuan. Dalam hal ini, metode hermeneutika yang telah muncul sebagai disiplin ilmu metode penafsiran menjadi salah satu alternatif dalam menafsirkan teks Alquran.

Hermeneutika telah digunakan di zaman Yunani Kuno sebagai salah satu kajian penafsiran Bibel. Islam juga memiliki metode "tafsir" sebelum hermeneutika muncul. Terlepas dari itu, terdapat beragam pandangan pro kontra akan pendekatan hermeneutika jika diaplikasikan pada Alquran yaitu sebagai kitab yang sakral bagi umat Muslim. Jika demikian, maka hermeneutika sebagaimana metodologi penafsiran kontemporer tidak bisa dikesampingkan. Sehingga perkembangan atau ranah keilmuan para mufassir bisa terupgrade dengan adanya teori hermeneutika, tentu tidak terlepas dari kaidah-kaidah tafsir yang harus memahami ulumul Quran dan metode tafsir yang ada. Sebagaimana tertuang dalam suatu kaidah "al-Muhafadhotu 'ala qadimi al-Shalih wa al-Akhdzu bi al-Jadid al-Aslab" (menjaga tradisi-tradisi lama sembari menyesuaikan dengan tradisi-tradisi modern adalah lebih baik. Upaya yang dimaksud adalah mengembangan sejumlah khazanahkhazanah keislaman yang toleran dan terbuka terhadap perbedaan serta kontekstualisasi dengan zaman kekinian. 
Hermeneutika Alquran |75

\section{DAFTAR PUSTAKA}

Anshari. (2009). Hermeneutika sebagai Teori dan Metode Interpretasi Makna Teks Sastra. Jurnal Sawergading, 15(2), 189.

Baits, Ammi Nur. (2018). Minum Air Unta Pengobatan Nabi. konsultasisyariah.com. Online.

Faiz, Fahruddin. (2015). Hermeneutika Alquran Tema-tema Kontroversial. Yogyakarta: Elsaq Press.

Goldziher, Ignaz. (2010). Mazhab Tafsir dari Klasik Hingga Modern. Yogyakarta: Elsaq Press.

Muflihah. (2012). Hermeneutika sebagai Metode Interpretasi Teks Alquran. Jurnal Mutawatir, 02(1), 47.

Mustaqim, Abdul. (2001). Studi Alquran Kontemporer Wacana Baru Berbagai Metodologi Tafsir. Jakarta: Tiara Wacana.

Muzayyin. (2015). Pendekatan Historis-Kritis dalam Studi Alquran (Studi Komparatif terhadap Pemikiran Theodor Noldeke dan Arthur Jeffery). TESIS, Program Studi Agama dan Filsafat, UIN Sunan Kalijaga Yogyakarta.

Muzayyin. (2015). Resepsi Hermeneutika dalam Penafsiran Alquran oleh M. Quraish Shihab. Nun, 1(1), 114-115.

Muzir, Inyiak Ridwan. (2016). Hermeneutika Filosofis Hans Georg Gadamer. Yogyakarta: Ar-Ruzz Media.

Pari, Fariz. Kafrawi, Shalahuddin. Mustaqim, Abdul. Wahyudi, Yudian. Ilyas, Hamim. Almirzanah, Syafa'atun dan dll. (2009). Upaya Integrasi Hermeneutika dalam Kajian Quran dan Hadits (Teori dan Aplikasi). Yogyakarta: Lembaga Penelitian UIN Sunan Kalijaga. 
Rahman, Mukhlish. (2017). Penafsiran Alquran Masa Modern dan Kontemporer. Kompasiana: Mahasiswa Jurusan Tafsir Hadits Fakultas Ushuluddin UIN Sunan Kalijaga.

Salim, Peter. (1997). The Contemporary English Indonesian Dictionary. Jakarta: Modern English Press.

Syamsuddin, Sahiron dkk. (2003). Heremeneutika Alquran Mą̧bab Yogya. Yogyakarta: Islamika.

t.n. (2018). Kontroversi 'Minum Kencing Unta' Bachtiar Nasir Jadi Perdebatan Politik. https://www.bbc.com. Online.

Victoria, Agro dan Kelib, Abdullah. (2017). Kontroversi Hermeneutika sebagai Manhaj Tafsir. Jurnal Hukum Khaira Ummah, 12(1), 9. 